БЕНЗЕН У ХРАНИ И РИЗИК ПО ЗДРАВЉЕ

Констанса Лазаревић ${ }^{1}$

\title{
BENZENE IN FOOD AND RISK FOR HEALTH
}

Konstansa Lazarević

\section{Сажетак}

Бензен је ароматични угљоводоник који припада Групи 1 хуманих канцерогена. Присутан је у животној средини, укључујући и храну, али су многи извори изложености хумане популације бензену недовољно познати. Циь овог рада је приказ резултата студија које су испитивале садржај бензена у храни, као и мера којима се може спречити негов настанак $y$ храни и сманити ризик по здравље услед изложености становништва бензену.

Кључне речи: бензен, освежавајућа безалкохолна пића, ризик по здравље.

\section{Summary}

Benzene is a volatile organic compound classified as a Group 1 carcinogen. May be found in the environment, including food, and many of source of benzene are not still unidentified. This review summaries the results of studies conducted in world on the content of benzene in food. This article also present formation mechanisms and methods how prevent formation of benzene in food, and also prevent risk for health from human exposure to benzene.

Key words: benzene, non alcoholic beverages, health risk.

\footnotetext{
${ }^{1}$ Доц. др мед. сц. Констанса Лазаревић, Државни универзитет у Новом Пазару, Департман за биомедицинске науке, Нови Пазар.
} 


\section{УВОД}

Б ензен је безбојна, лако испарљива и запаљива течност карактеристичног мириса, која припада групи ароматичних хидрокарбоната. Настаје као последица вулканске активности, шумских пожара, емисије издувних гасова моторних возила и радом индустрије (користи се за производњу пластике, гуме, боје, детерџената, лекова и пестицида). Значајно је присутан у дуванском диму. ${ }^{(1)}$

Хумана популација је највећим делом изложена бензену преко ваздуха, док је учешћеводе и хранеу дневномуносу бензена јако мало. Осим особа професионално изложених бензену, због његовог присуства у дуванском диму, значајно су му изложене и особе које пуше и пасивни пушачи. ${ }^{(2,3)}$

Биомониторингом су утврђене високе концентрације метаболита бензена код деце и особа које не пуше, и нису професионално изложене бензену - можемо закључити да многи извори експозиције бензену још увек нису познати. ${ }^{(4)}$

Бензен припада првој групи хуманих канцерогена. Услед акутне изложености бензену јављају се замор, вртоглавица, слабост, крварење слузокоже и апластична анемија, а хронична изложеност може довести до настанка леукемије. ${ }^{(5,6)}$

Искористљивост орално унетог бензена је скоро $100 \%$. Овај канцероген има и кумулативни ефекат у организму, а број студија које су испитивале садржај бензена у храни је јако мали. ${ }^{(7,8)}$ Од када је 1990. године откривено присуство бензена у освежавајућим пићима на тржишту САД ${ }^{(9)}$, поставља се питање на које све начине можемо бити експонирани бензену.

\section{ЦИЈ РАДА}

Циљ овог рада је приказ студија које су испитивале концентрацију бензена у храни, унос бензена храном, као и приказ мера које могу спречити његов настанак у храни и смањити ризик по здравље.

\section{БЕНЗЕН У ХРАНИ И КАКО СПРЕЧИТИ ЊЕГОВ НАСТАНАК?}

Бензен у храну може доспети из спољне средине: контаминацијом воде која се користи у производњи и припреми хране (из индустријских испуста, депонија и акцидената), ${ }^{(10,11)}$ преко угљен-диоксида контаминираног бензеном, ${ }^{(12)}$ или из амбалаже у коју се пакују намирнице. ${ }^{(13)}$

Бензен може да се синтетише и током екстракције биљних уља хексаном, ${ }^{(14)}$ димљења и иридације намирница, или када се намирнице излажу високој температури. У таквим условима, распадањем појединих аминокиселина и других састојака хране долази до формирања бензена. ${ }^{(15-17)}$ Lachenmeir и сарадници наводе да се на температури од $150^{\circ} Ц$ у трајању од 2 сата бензен формира из прекурсора, као што су бета каротен, фенилаланин и неки терпени. ${ }^{(17)}$

Многе намирнице природно, или као конзерванс (освежавајућа пића, конзервисано поврће и др.) садрже бензоате или бензоеву киселину, чијом декарбоксилацијом у присуству хидрокси радикала може настати бензен. ${ }^{(18)}$

До декарбоксилације бензоата у бензен може доћи у присуству светлости и УВ зрачења, витамина Ц или изомера витамина Ц. Неке супстанце могу спречити настанак бензена у освежавајућим пићима. То су EDTA (етилен диаминтетрасирћетна киселина), шећер и концентровани фруктозни кукурузни сируп. ${ }^{(19,20)}$

Формирање хидрокси радикала је повећано у присуству јона бакра или јона гвожђа (Cu2+или $\mathrm{Fe} 3+)$, а зависи и од $\mathrm{pH}$ вредности намирнице. Максимално 
формирање бензена је при рН 2, а при вишим вредностима $\mathrm{pH}$ значајно је мање формирање бензена. ${ }^{(21)}$

На концентрацију бензена утиче и врста амбалаже у којој су паковане намирнице. Концентрација бензена већа од 10 ppb утврђена је у краставцима и капру конзервисаним бензоатима и аскорбинском киселином, пакованим у пластичне кесице и чуваним на собној температури, а значајно мање вредности у производима пакованим у стакленој амбалажи. ${ }^{(22)}$ И освежавајућа пића пакована у пластичну амбалажу имала су већу концентрацију бензена у односу на пића пакована у стаклену амбалажу или конзерве. ${ }^{(23)}$

Избегавањем свих напред наведених услова у току производње и промета може се спречити настанак бензена у току технолошког процеса, али и транспорта и складиштења хране.

\section{РЕЗУЛТАТИ ИСПИТИВАНА БЕНЗЕНА У ХРАНИ}

Осамдесетих година двадесетог века присуство бензена утврђено је у воћу, риби, поврћу, коштуњавом воћу, млечним производима, пићима и јајима. Јаја су имала највеће концентрације бензена $(2,100 \mathrm{ppb}$ (некувана) и 500-1,900 ppb (тврдо кувана), затим бакалар (100-200 ppb), и рум са Јамајке (120 ppb). Кувано месо - јагњетина, овчетина, телетина, пилетина имали су вредности бензена $<10$ ppb. ${ }^{(24)}$

Анализом више од 50 намирница у периоду од 1991. до 1992. године утврђено је да храна (укључујући и јаја) без додатих бензоата садржи бензен у веома ниским концентрацијама $<2 \mathrm{ppb}$. Ниво бензена у храни без додатих бензоата поред аскорбата кретао се од 1 до $<38$ ppb. ${ }^{(19)}$

У току петогодишње студије спроведене у САД, ${ }^{(7)}$ утврђено је да сви анализирани узорци хране садрже бензен - са изузетком америчког сира и сладоледа од ваниле. Намирнице са највећом максимално измереном концентрацијом бензена биле су млевена говедина (190 ppb), сирове банане (132 ppb), газирана кола (138 ppb), и салата од купуса са преливом (102 ppb). FDA (Food and Drug Administration) је упозорила на чињеницу да је бензен могао настати у току хемијске анализе, те да су резултати непоуздани, као и да је неопходно усавршити аналитичку методу.

Препоруке за максимално дозвољену концентрацију бензена предвиђене су само за воду за пиће. Разликују се широм света - C3О препоручује - 10 ppb, ${ }^{(25)}$ EPA (The United States Environmental Protection Agency) - 5 $\mathrm{ppb}{ }^{(26)}$ а у Европској унији ${ }^{(27)}$ износи само $1 \mathrm{ppb}$.

У студији спроведеној у Италији, објављеној 2001. године, свих 60 узорака освежавајућих пића имало је вредности бензена мање од максимално дозвољених од С3О за бензен у води за пиће. ${ }^{(28)}$ У другој, из 2008. године, од 28 анализираних узорака освежавајућих пића која су садржала бензоеву или сорбинску киселину и витамин Ц, два узорка имала су концентрацију бензена већу од лимита прописаног у ЕУ за воду за пиће. ${ }^{(29)}$

У новембру 2005. године, FDA је добила захтев од неколико приватних лабораторија да се испита бензен у освежавајућим пићима. Од преко 100 анализираних освежавајућих пића која садрже и бензоате или аскорбинску или еритборичну киселину, само четири узорка садржало је концентрације бензена веће од законског лимита за воду за пиће (до $5 \mathrm{ppb}$ ) у САД. ${ }^{(30)}$ Један од та четири производа - сок од бруснице - имао је додат витамин Ц, али не бензоате. Неке врсте воћа (као што су брусница, шљива и др.) природно садрже бензоате. Ако се њиховим соковима дода витамин Ц, може настати бензен, што је био случај код сока од бруснице. Сва четири производа су реформулисана од стране произвођача како би се постигло да концентрација буде испод лимита детекције. 
У Великој Британији је само четири од 150 анализираних узорака освежавајућих пића садржало вредности бензена веће од 10 ppb, ${ }^{(31)}$ а у Канади два од 124 анализирана освежавајућа пића. ${ }^{(32)}$ У аустралијским ароматизованим освежавајућим пићима 38 узорака имало је вредности бензена од 1 do $40 \mu \mathrm{g} / \mathrm{kg} .{ }^{(33)}$

У Ирској од 63 анализирана освежавајућа пића - у 54 (86\%) узорка бензен је био испод лимита детекције, а 2 узорка имала су вредности бензена веће од 10 ppb. ${ }^{(34)}$

Присуство бензена испитивано је и у освежавајућим пићима у Белгији. ${ }^{(23)}$ Од 134 анализирана узорка, код 33\% није детектован бензен, а само један узорак имао је вредности бензена веће од 10 ppb.

Резултати до сада објављених истраживања указује да не постоји здравствени ризик од уноса бензена освежавајућим пићима.

У Немачкој је испитиван 451 узорак сокова и освежавајућих пића. Бензен је у пићима имао ниске концентрације испод лимита за воду за пиће у ЕУ. Значајно веће концентрације су утврђене у соку од шаргарепе за малу децу. Око 94\% узорака сока од шаргарепе имало је просечну концентрацију бензена - $1.86+/-1.05 \mu \mathrm{g} / 1$. Можемо закључити да на овај начин и здравље најмлађих може бити угрожено. ${ }^{(18)}$

\section{ИЗЛОЖЕНОСТ ХУМАНЕ ПОПУЛАЦИЈЕ БЕНЗЕНУ ПРЕКО XPAHE}

Becalski and Nyman указују на велике разлике између резултата студија које су испитивале унос бензена храном. ${ }^{(2)}$ Постоји неколико објашњења за овакве резултате. У истраживањима у којима су коришћене вредности бензена у храни добијене недовољно прецизним методама (а које је објавила FDA), унос бензена храном био је знатно већи. Максималан дозвољени дневни унос бензена храном, за који се претпоставља да не представља ризик по здравље, предложен од ATSDR (Agency for Toxic Substances and Disease Registry) износи 0.5 $\mu \mathrm{g} / \mathrm{kg}$ телесне масе/дневно. ${ }^{(35)}$

Очигледно је да су различите групе намирница извори бензена, у зависности од резултата хемијских анализа које су коришћене за испитивање уноса бензена храном.

Због тога је неопходно развити нове поуздане аналитичке методе за испитивање бензена у храни, и спровести национална истраживања у свакој земљи појединачно.

Приказ резултата до сад спроведених студија дат је у Табели 1.

Табела 1. Резултати студија које су испитивале просечан дневни унос бензена храном.

\begin{tabular}{|c|c|c|}
\hline Земља & $\begin{array}{l}\text { Унос бензена } \\
(\mu \mathrm{g} / \mathrm{kg} \text { телесне масе/дневно) }\end{array}$ & Литература \\
\hline Канада & $0.007-0.275$ & $\begin{array}{l}\text { Environment Canada and Health Canada, } \\
\text { 1993. }{ }^{(36)}\end{array}$ \\
\hline $\begin{array}{l}\text { Велика } \\
\text { Британија }\end{array}$ & $\begin{array}{l}0.025 \\
0.04\end{array}$ & $\begin{array}{l}\text { DEFRA, 2003. }{ }^{(37)} \\
\text { Environment Agency, 2009. }{ }^{(38)}\end{array}$ \\
\hline САД & $\begin{array}{l}0.007-0.013 \text { (пића) } \\
0.007\end{array}$ & $\begin{array}{l}\text { Haws et al., 2008. }{ }^{(39)} \\
\text { Moschandreas et al., 2002. }\end{array}$ \\
\hline Белгија & 0.020 & Medeiros Vinci et al, 2012. ${ }^{(8)}$ \\
\hline
\end{tabular}


Анализом 455 узорака намирница на белгијском тржишту, бензен је утврђен код $58 \%$ анализираних узорака. Био је присутан у свим прехрамбеним категоријама са изузетком свежих јаја. У мање од $10 \%$ анализираних узорака алкохолних пића, воћа и поврћа, детектован је бензен, а у 66-96\% узорака сосова, меса и месних прерађевина, рибе и рибљих производа, производа од житарица, торти и колача, масти и уља, и готових јела измерене су вредности веће од лимита детекције. Највећа концентрација бензена утврђена је код рибе и рибљих производа и димљених и конзервираних рибљих производа. Из тог разлога, највеће учешће у уносу бензена (78\% процењеног дневног уноса) имали су риба и производи од рибе, освежавајућа пића, готова јела и месо и производи од меса. ${ }^{(8)}$

\section{ЗАКЈЉУЧАК}

Резултати до сада објављених истраживања указују да не постоји здравствени ризик од уноса бензена храном. Имајући у виду кумулативно дејство које овај канцероген има у организму (хумана популација је значајно изложена и преко ваздуха и воде), неопходно је елеминисати његово присуство у храни. Неодговарајући технолошки поступци у производњи и преради хране, као и контаминација хране бензеном пореклом из амбалаже или спољне средине, може довести до присуства бензена у храни.

Не постоје студије које су испитивале садржај бензена у храни на тржишту Србије. Неопходно је спровести ова истраживања, како би се утврдило које намирнице значајно учествују у његовом уносу. Едукација произвођача и продаваца о мерама за спречавање настанка бензена у храни смањила би могући ризик по здравље настао уносом бензена храном.

\section{ЛИТЕРАТУРА}

1. Jedra M, Starski A. Benzene in food and human environment. Rocz Panstw Zakl Hig 2010; 61(1): 7-12.

2. Becalski A., Nyman P. Benzene. In: Stadler RH, Lineback DR. (Eds.). ProcessInduced Food Contaminants - Occurrance, Formation, Mitigation, and Health Risks. Wiley, 2009. pp. 413-444.

3. Department for Environment, Food and Rural Affairs and Environment Agency (DEFRA), 2003. Contaminants in soil: collation of toxicological data and intake values for humans. Benzene.

4. Johnson ES, Langård S, Lin YS. A critique of benzene exposure in the general population. Sci Total Environ 2007; 374: 183-98.
5. Galbraith D, Gross SA, Paustenbach D. Benzene and human health: A historical review and appraisal of associations with various diseases. Crit Rev Toxicol 2010; 40 Suppl 2: $1-46$.

6. IARC, 1987. Benzene - IARC Monographs on the Evaluation of Carcinogenic Risks to Humans, $1-42$ ed. International Agency for Research on Cancer, France, Lyon (Suppl. 7).

7. Fleming-Jones ME, Smith RE. Volatile organic compounds in foods: a five year study. J Agric Food Chem 2003; 51(27): $8120-7$.

8. Medeiros Vinci R, Jacxsens L, Van Loco J, Matsiko E, Lachat C. et al. Assessment of human exposure to benzene through foods from the Belgian market. Chemosphere 2012; 88(8): $1001-7$. 
9. No authors listed. Beverage ingredients can form carcinogen. Consum Rep. 2006; 71(10): 7.

10. Lindstrom AB, Highsmith VR, Buckley TJ, Pate WJ, Michael LC. Gasolinecontaminated ground water as a source of residential benzene exposure: a case study. J Expo Anal Environ Epidemiol 1994; 4: $183-95$.

11. Environment Agency, 2009.

Contaminants in soil: updated collation of toxicological data and intake values for humans Benzene. Better Regulation Science Programme Science report: SC050021. Available from: http://publications. environment-agency.gov.uk

12. Wu QJ, Lin H, Fan W, Dong JJ, Chen HL. Investigation into benzene, trihalomethanes and formaldehyde in Chinese lager beers. J Inst Brew 2006; 112(4): 291-294.

13. Varner SL, Hollifield HC, Andrzejewski

D. Determination of benzene in polypropylene food-packaging materials and food-contact paraffin waxes. J Assoc Off Anal Chem 1991; 74 (2): 367-374.

14. Masohan A, Parsad G, Khanna MK, Chopra SK, Rawat BS, Garg, MO.

Estimation of trace amounts of benzene in solvent extracted vegetable oils and oil seed cakes. Analyst 2000; 125(9): 1687-1689.

15. Wittkowski R, Baltes W, Jennings WG. Analysis of liquid smoke and smoked meat volatiles by headspace gas-chromatography. Food Chem 1990; 37(2): 135-144.

16. Ahn DU. Production of volatiles from amino acid homopolymers by irradiation. J Food Sci 2002; 67(7): 2565-2570.

17. Lachenmeier DW, Kuballa T, Reusch H, Sproll C, Kersting M, Alexy U. Benzene in infant carrot juice: Further insight into formation mechanism and risk assessment including consumption data from the DONALD study. Food Chem. Toxicol 2010; 48(1): 291-297.
18. Lachenmeier DW, Reusch H, Sproll C, Schoeberl K, Kuballa, T. Occurrence of benzene as a heat-induced contaminant of carrot juice for babies in a general survey of beverages. Food Addit. Contam. 2008; A 25: 1216-1224.

19. McNeal TP, Nyman PJ, Diachenko GW, Hollifield HC. Survey of benzene in foods by using headspace concentration techniques and capillary gaschromatography. J AOAC Int 1993; 76(6): 1213-1219.

20. Nyman PJ. Summary of an investigation of the reliability of benzene results from the total diet study. Washington, D.C.: USFDA/ CFSAN/OFAS/DCRER, 2006.

21. Gardner LK, Lawrence GD. Benzene production from decarboxylation of benzoic-acid in the presence of ascorbicacid and a transition-metal catalyst. J Agric Food Chem 1993; 41(5): 693-695.

22. Casado FJ, Sánchez AH, De Castro A, Rejano L, Beato VM, Montaño A. Fermented vegetables containing benzoic and ascorbic acids as additives: benzene formation during storage and impact of additives on quality parameters. J Agric Food Chem 2011; 59(6): 2403 - 9.

23. Van Poucke C, Detavernier C, Van Bocxlaer JF, Vermeylen R, Van Peteghem C. Monitoring the benzene contents in soft drinks using headspace gas chromatography-mass spectrometry: a survey of the situation on the belgian market. J Agric Food Chem. 2008; 56(12): 4504-4510.

24. ATSDR. (Agency for Toxic Substances and Disease Registry) (1993): Toxicological profile for benzene. Atlanta, GA, US Department of Health and Human Services.

25. WHO. Benzene in drinking-water. Background document for the development of WHO guidelines for drinking water quality, World Health Organization, Geneva, 1996. 
26. US EPA. Final draft for drinking water criteria document on benzene. Health Effcets Branch: Criteria and Standards Division, 1985.

27. EC. Council Directive 98/83/EC on the quality of water intended for human consumption. http://eur-lex.europa.eu.L330

28. Fabietti F, Delise M, Piccioli Bocca A. Investigation into the benzene and toluene content of soft soft drinks. Food Control 2001; 12(8): 505 - 509.

29. Bonaccorsi G, Perico A, Colzi A, Bavazzano P, Di Giusto M, Lamberti I. et al. Benzene in soft drinks: a study in Florence (Italy) Ig Sanita Pubbl. 2012; 68(4): 523532.

30. Meadows M. Benzene in beverages. FDA Consumer 2006; 4: 9-10.

31. Food Standards Agency. 2006. Food Survey Information Sheet No. 6/06. Survey of benzene in soft drinks. Food Standards Agency, London, UK, 2006.

32. Cao XL, Casey V, Seaman S, Tague B, Becalski A. Determination of benzene in soft drinks and other beverages by isotope dilution headspace gas chromatography/ mass spectrometry. Journal of AOAC International 2007; 90: 479-484.

33. Anon. Benzene in flavoured beverages. World Food Regulation Review 2006; 16: 3.

34. Food Safety Authority of Ireland (2008). Investigation into the levels of benzene in soft drinks, squashes and flavoured waters. Report available at http://www. fsai.ie/surveillance/food_safety/chemical/ benzene 08/benzene 08 index.asp
35. ATSDR, 2007. ToxGuideTM for Benzene C6H6, CAS \#71-43-

2. <http:// www.atsdr.cdc.gov/ toxguides 36 . Environment Canada and Health and Welfare Canada (1993). Canadian Environmental Protection Act. Priority Substances List assessment report: Benzene. Minister of Supply and Services Canada, Ottawa, Ontario (www.hc-sc.gc.ca/ ewh-semt/pubs/contaminants/psl1-lsp1/ benzene/index_e.html)

37. DEFRA, 2003. Contaminants in soil: collation of toxicological data and intake values for humans. Benzene. Available from: http://www.safegrounds.com/pdf/ clr9 contaminants in soil.pdf

38. Environment Agency, 2009.

Contaminants in soil: updated collation of toxicological data and intake values for humans Benzene. Better Regulation Science Programme Science report: SC050021. Available from: http://publications. environment-agency.gov.uk

39. Haws LC, Tachovsky JA., Williams ES, Scott LLE, Paustenbach DJ, Harris MA. Assessment of potential human health risks posed by benzene in beverages. J Food Sci 2008; 73: T33 - T41.

40. Moschandreas DJ, Karuchit S, O'Rourke MK, Lo D, Lebowitz MD, Robertson G. Exposure apportionment: Ranking food items by their contribution to dietary exposure. J Expo Anal Env Epid 2002; 12: 233-243.

Контакт: Доц. др мед. сц. Констанса Лазаревић, Државни универзитет у Новом Пазару, Департман за биомедицинске науке, Вука Караџића бб, 36300 Нови Пазар, e-mail: koni33@hotmail.com 